\title{
Unveiling asexual reproductive traits in black corals: polyp bail- out in Antipathella subpinnata
}

\author{
Martina Coppari ${ }^{1,2}(\mathbb{D}) \cdot$ Lara Fumarola $^{3,4}$ - Lorenzo Bramanti $^{4}$ - Pascal Romans ${ }^{5}$. \\ Rémi Pillot ${ }^{5}$ Giorgio Bavestrello ${ }^{1,2} \cdot$ Marzia Bo ${ }^{1,2}$
}

Received: 22 June 2020/ Accepted: 14 October 2020/Published online: 28 October 2020

(C) The Author(s) 2020

\begin{abstract}
Cnidarians are known to undergo reverse development as a survival mechanism against adverse environmental conditions. Polyp bail-out consists in the polyps' detachment from the mother colony due to stressful conditions, followed by a complete tissue and cells rearrangement and in some cases in a regression into a simple, ciliated form. Here we describe a massive polyp bail-out event occurred in the mesophotic black coral Antipathella subpinnata in reared conditions. This is the first report of a bail-out event in this species providing new insights into the life cycle and ecology of black corals.
\end{abstract}

Keywords Antipatharians - Asexual reproduction - Bailout · Aquaria

Topic Editor Anastazia Teresa Banaszak

Electronic supplementary material The online version of this article (https://doi.org/10.1007/s00338-020-02018-1) contains supplementary material, which is available to authorized users.

Martina Coppari

coppari.martina85@gmail.com

1 Dipartimento di Scienze della Terra, dell'Ambiente e della Vita, Università degli studi di Genova, Genoa, Italy

2 CoNISMa, Rome, Italy

3 Dipartimento di Scienze e Tecnologie Biologiche e Ambientali, Università del Salento, Lecce, Italy

4 CNRS-Sorbonne Université, Laboratoire d'Ecogéochimie des Environnements Benthiques, LECOB, Observatoire Océanologique de Banyuls sur Mer, Banyuls-sur-Mer, France

5 Service Mutualisé d'Aquariologie, Observatoire Océanologique de Banyuls, FR3724. Sorbonne Université CNRS, Banyuls-sur-Mer, France

\section{Introduction}

Polyp bail-out, the active detachment of polyps from the mother colony (Sammarco 1982), is an extreme response serving as a survival and escape strategy under unfavorable environmental conditions, which could lead to the death of the mother colony (Peter III et al. 2014; Fordyce et al. 2017). Polyp bail-out represents an example of reverse development (Piraino et al. 2004) in which a detached polyp undergoes complete tissue and cell rearrangement with loss of the compartment structure present in the primary polyp (Kariyazono and Hatta 2015). Until now, this phenomenon has been described only in aquaria, even though its presence is hypothesized in natural conditions (Miller and Grange 1997).

Indeed, the capability of cnidarians to undergo polyp bail-out highlights their high plasticity to shift from a colonial to a solitary form and vice versa (Kvitt et al. 2015) and, for many Anthozoa, from a sessile to a motile form, escaping unsuitable environments or interspecific competition (Lee et al. 2012), thus enabling survival in extreme conditions.

The process of bail-out differs from polyp expulsion, which is an asexual reproductive strategy occurring in physiologically healthy coral and regulated by the parent colony (Kramarsky-Winter et al. 1997).

The species able to produce bail-out propagules studied so far include shallow tropical (Sammarco 1982, Capel et al. 2014; Shapiro et al. 2016; Fordyce et al. 2017) and temperate scleractinians (Kružic 2007; Serrano et al. 2018), as well as deep cold-water and tropical octocorals (Rakka et al. 2019; Wells and Tonra 2020). This phenomenon occurs or can be mechanically induced (e.g., by cutting the tentacles) also in antipatharian species (Parker et al. 1997; Bo 2008; Gonçalves 2016). 
Antipathella subpinnata (Ellis and Solander, 1786) is the most frequent black coral species of Mediterranean Temperate Mesophotic Ecosystems (TMEs) (i.e., communities found below PAR 1\%, approximately between 40 and $260 \mathrm{~m}$ depth) (Bo et al. 2019a; Cerrano et al. 2019). It forms forest-like aggregations (animal forest, sensu Rossi et al. 2017), providing a tridimensional habitat and refuge or nursery area for many associated species (Bo et al. 2019b). A. subpinnata is gonochoric, reproduces sexually at the end of summer (Gaino and Scoccia, 2010) and asexually through fragmentation (Coppari et al. 2019). Until now, asexual reproduction has been observed only in aquaria, but its presence in natural environments could not be excluded (Costantini et al. 2019).

Considering that no detailed description of the bail-out process exists for antipatharians, in the present paper, we describe for the first time, this phenomenon in A. subpinnata, under controlled conditions.

\section{Materials and methods}

Six Antipathella subpinnata colonies (height ranging between 50 and $80 \mathrm{~cm})$ were sampled in Bordighera $\left(43^{\circ}\right.$ $\left.46.11^{\prime} \mathrm{N} ; 7^{\circ} 40.82^{\prime} \mathrm{E}\right)$ at $63 \mathrm{~m}$ depth on July 9, 2018 (Fig. 1a). Immediately after sampling, each of the colonies was placed at the bottom of a tank (144 L) filled with seawater collected at $60 \mathrm{~m}$ depth by a $10 \mathrm{~L}$ Niskin bottle and kept at constant temperature $\left(T=14{ }^{\circ} \mathrm{C}\right.$, same as the sampling site) during the transport. After approximately $10 \mathrm{~h}$, colonies were transferred to Banyuls-sur-Mer Aquarium facilities (Biodiversarium) and positioned in an open circuit 2000-L tank (Fig. 1b) filled with filtered $(0.2 \mathrm{~mm})$ seawater taken at $20 \mathrm{~m}$ depth. Constant tank temperature $\left(14^{\circ} \mathrm{C}\right)$ was ensured by both a refrigerator system and a thermostatic room also equipped with blue lights to simulate the natural light regime $\left(0-5 \mu \mathrm{mol} \mathrm{m} \mathrm{m}^{-2}\right.$ $\mathrm{s}^{-1}$; photoperiod: $12 \mathrm{~h}$ day and $12 \mathrm{~h}$ night). Two submersible water pumps were used to ensure water movement; salinity and temperature were checked daily, while the ratio of $\mathrm{NH}_{3} / \mathrm{NH}_{4}$ and the values of $\mathrm{NO}_{2}, \mathrm{NO}_{3}, \mathrm{PO}_{4}, \mathrm{pH}$ and copper were checked once per month. Colonies were fed twice a day with Artemia nauplia and Rotifera.

To catch the propagules, the main aquarium wastewater passed through a PVC cylinder equipped with a $0.2 \mathrm{~mm}$ net (propagules trap) placed in a tank on the side of the main tank. Bail-out propagules retrieved in the trap were collected and observed with a dissecting microscope to study their morphology. Propagule size was measured from pictures using the software Fiji-ImageJ (Schindelin et al. 2012). To quantify variability in shape and survival, 10 bail-out propagules were randomly collected every day, measured, preserved in small beakers filled with filtered seawater $(0.2 \mu \mathrm{m})$ and monitored every 3 days for 45 days.

Scanning Electron Microscope (SEM) observations were performed to examine the propagules external structure including their cnidome.

Histological examination after resin inclusion was also performed to study the internal structure of the propagules: samples were fixed in $70 \%$ ethanol and then dehydrated in a graded ethanol series followed by inclusion in a coldcuring resin and finally mounted on plastic supports. The sections ( $9 \mu \mathrm{m}$ thick) obtained by a microtome were colored with Toluidine blue, then analyzed on a compound microscope.

\section{Result and discussion}

One month after the transport to the aquarium facilities, colonies started to form motile and negative buoyant bailout propagules (ESM 1). The process started with coenosarc withdrawal from the apical branches of the mother colony, followed by detachment from the skeleton and subsequent expulsion and ended with the formation of freeliving propagules (Fig. 2a; ESM 1). The portion of the colony releasing propagules underwent necrosis and consecutive death. In addition to necrosis and polyp bail-out, we observed fragmentation of mother colonies' branchlets. Moreover, gamete reabsorption, by two of the six colonies that were fertile at the time of sampling, was observed by means of polyps' dissection and histology. The bail-out phenomenon was massive, with hundreds of propagules produced daily; thus, dissecting microscope observations were performed on a subsample of 2585 randomly selected propagules. Four main morphologies were observed (Fig. 2b): circular (74\%, $n=1915)$; elongated (13\%, $n=335)$; polypoid (10\%, $n=248$ ) (Fig. 2b); and "other" ( $3 \%, n=87)$. Regardless of the morphology, all propagules were actively moving by rotation on multiple axes (ESM 1). Hundred propagules for each shape were measured, and results are listed in Table 1.

Most of the propagules assumed the circular morphology (Fig. 2c). Nearly all selected propagules survived for the whole period of observation; however, settlement has never been observed.

The histological analysis allowed a description of the internal anatomy of all propagules types (Fig. $3 \mathrm{a}-\mathrm{c}$ ). The shape of the circular propagule in transversal section suggests it was either a fragment of a tentacle or a later developmental stage of the elongated or polypoid shape. The elongated propagule, in longitudinal section, had a cylindrical shape, with a rounded distal end and an enlarged base, suggesting it derived from a whole tentacle (base included) detached from a polyp. The polypoid shape 
Fig. 1 A forest of Antipathella subpinnata at the sampling site (Bordighera, $63 \mathrm{~m}$ depth) (a), the experimental tank $(2000 \mathrm{~L})$ at the Biodiversarium facilities, with visible colonies (b)
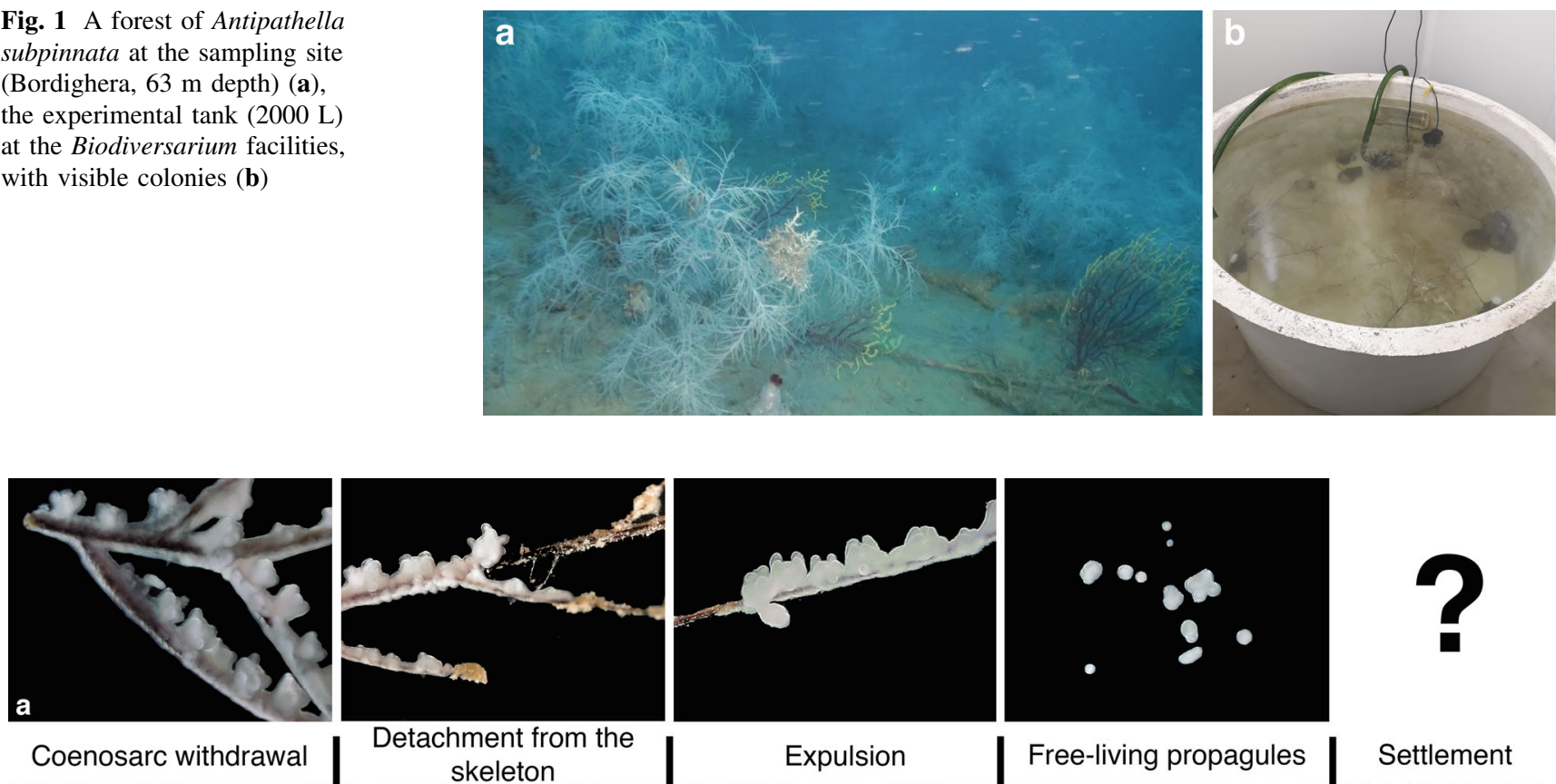

\section{Detachment from the} skeleton

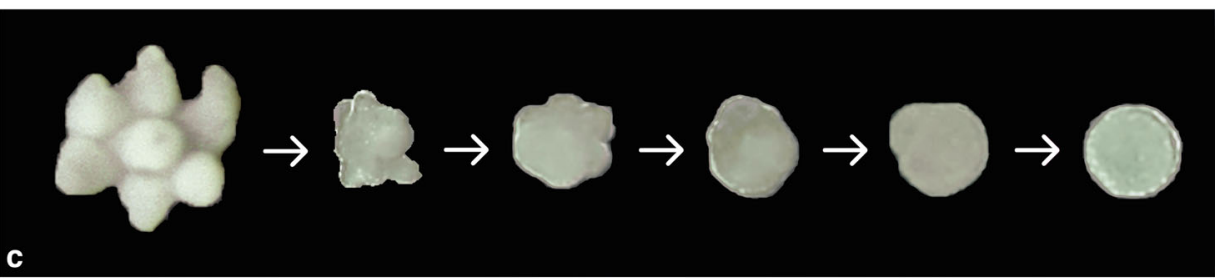

b

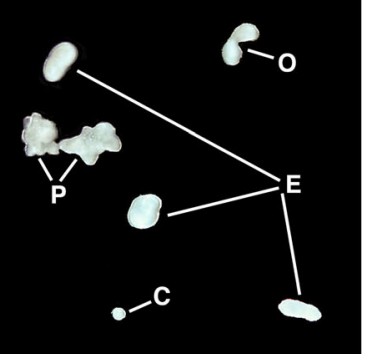

Fig. 2 Phases of the polyp bail-out formation, with settlement not observed in this study (a), different morphologies of the propagules: circular $(\mathrm{C})$, elongated $(\mathrm{E})$, polypoid $(\mathrm{P})$ and other $(\mathrm{O})(\mathbf{b})$, shape modification toward the circular $(\mathbf{c})$

was more variable depending on how many tentacles detached. In the observed transversal section, a tripartition was visible, and signature of the sagittal tentacles surrounded the original gastric cavity, where mesenteries were still visible.

In each propagule, it was possible to recognize external and internal layers, derived from the epidermis and from the re-organization of the gastroderm, respectively, and separated by an amorphic mesoglea (Fig. 3a-c). The epidermal layer was characterized by a dense palisade of muciparous cells. Sparse and spherical structures were visible in the gastroderm, suggesting the occurrence of vacuoles. Few nematocysts (basitrich isorhiza, $9 \mu \mathrm{m}$ long and $2.3 \mu \mathrm{m}$ wide) were observed in the epidermal layer (Fig. 3d), some of which exploded (Fig. 3e). Their size was consistent with adult colonies' ones (Fig. 3f).

The presence of nematocyst capsules was also observed with SEM analysis on the surface of propagules (Fig. 3g, h). The epidermal layer was covered with extruded barbs (Fig. 3i) with a distinct set of spines spirally arranged

Table 1 Size of the three main bail-out morphologies: circular $(C)$, elongated $(E)$, polypoid $(P), n=100$, SD indicates the standard deviation

\begin{tabular}{lllllll}
\hline $\begin{array}{l}\text { Shape } \\
(\mathrm{mm})\end{array}$ & $\begin{array}{l}\text { Average long side } \pm \mathrm{SD} \\
(\mathrm{mm})\end{array}$ & $\begin{array}{l}\text { Average short side } \pm \mathrm{SD} \\
(\mathrm{mm})\end{array}$ & $\begin{array}{l}\text { Max long side } \\
(\mathrm{mm})\end{array}$ & $\begin{array}{l}\text { Max short side } \\
(\mathrm{mm})\end{array}$ & $\begin{array}{l}\text { Min short side } \\
(\mathrm{mm})\end{array}$ \\
\hline$C$ & $0.26 \pm 0.12$ & - & 0.78 & 0.09 & - & - \\
$E$ & $0.50 \pm 0.15$ & $0.34 \pm 0.11$ & 0.92 & 0.18 & 0.81 & 0.10 \\
$P$ & $0.73 \pm 0.28$ & $0.42 \pm 0.14$ & 1.49 & 0.25 & 0.89 & 0.13 \\
\hline
\end{tabular}



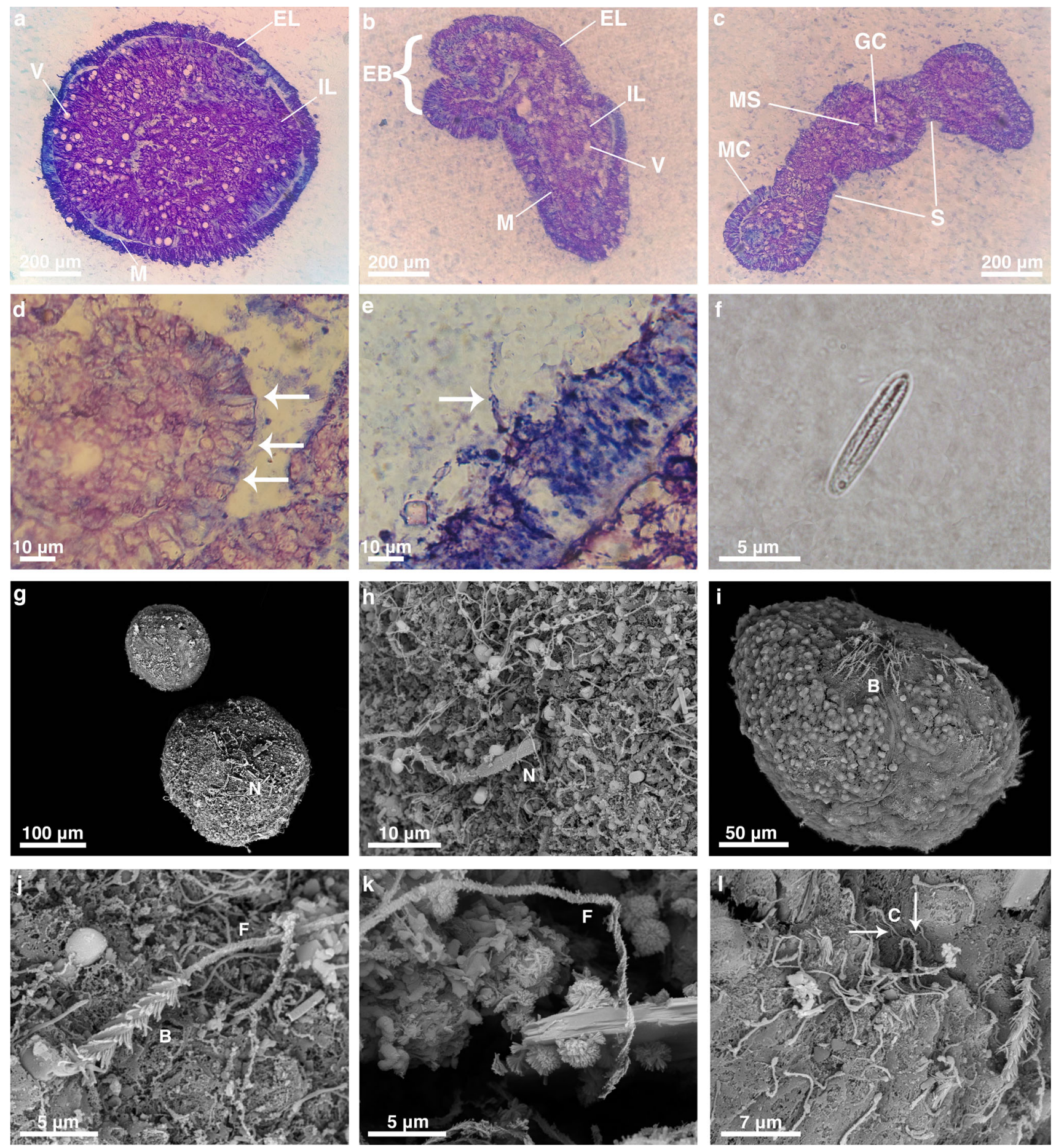

Fig. 3 Internal anatomy of the circular (a), elongated (b) and polypoid (c), propagules show the presence of an epidermal layer (EL), an internal layer (IL), the mesoglea $(M)$ and the vacuoles ( $V)$ (a). The enlarged base (EB) of the elongated propagules is also evident (b) while in $\mathbf{c}$ the original polyp gastric cavity is visible (GC), together with the mesenteries (MS). Septa $(S)$ of epidermal tissue as well as muciparous cells (MC) are also visible. White arrows indicate the basitrich isorhizas observed in the epidermal layer (d), whereas in e the arrow points to one exploded nematocyst. f Shows the detail of a basitrich isorhizas of an adult specimen. SEM images highlighting the presence of nematocyst capsules $(N)$ on the surface of circular bailout propagules (g), close-up of the nematocyst capsule (h), several exploded nematocysts with evident barbs $(B)$ on the surface of the propagule (i), exploded nematocyst with barb and filament $(F)(\mathbf{j})$, close-up of the structure of the filament $(\mathbf{k})$, presence of cilia $(C$ and white arrows) on the surface of the propagule (l) 
(Fig. 3j) and a spiny filament (Fig. 3j, k). On the propagules' surface, cilia with thinner diameter and smoother surface than filaments were observed (Fig. 31).

The coenosarc withdrawal followed by detachment from the skeleton and formation of free-living propagules observed in our samples (Fig. 2) allowed classifying this phenomenon as polyp bail-out. However, while the shape modification observed in A. subpinnata was reported for another antipatharian species (Bo 2008), and for gorgonian species (Rakka et al. 2019), it was not observed in the scleractinian Pocillopora damicornis (Kvitt et al. 2015), suggesting different propagules formation mechanisms in distinct taxa.

In black corals, the bail-out phenomenon was observed either by mechanical induction in Antipathes sp. (Bo 2008), Antipathes caribbeana Opresko 1996 and Plumapathes pennacea (Pallas, 1766) (Gonçalves, 2016) or triggered by stressful conditions in the congeneric Antipathella fiordensis (Grange, 1990) (Parker et al. 1997). In all these studies, the detachment of a whole polyp or a polyp fragment resulted in the formation of motile propagules. The present study confirmed that antipatharians are able to spontaneously form motile bail-out propagules. According to our observations, bail-out propagules can originate also from polyp portions (tentacles), a mechanism which has never been observed in other coral species and which resembles pinnitomy, an asexual reproductive strategy, reported for octocorals, in which tentacular pinnules can autotomize and detach from the parent colony forming a new polyp and potentially, new colonies (Gohar 1940).

Black corals propagules can display different movement patterns with Antipathes sp. (Bo 2008) and A. subpinnata propagules rotating on multiple axes (ESM1, ESM2), dissected $A$. caribbeana tentacles moving as a torpedo and $P$. pennacea ones oscillating around a main axis (Gonçalves 2016).

Stressful conditions known to trigger the polyp bail-out in cnidarians include the decrease in $\mathrm{O}_{2}$ concentration (Sammarco 1982; Rakka et al. 2019), temperature increase (Kružic 2007; Fordyce et al. 2017; Rakka et al. 2019), the secondary metabolites produced by macroalgae (Lee et al. 2012), changes in salinity (Shapiro et al. 2016) and $\mathrm{pH}$ (Kvitt et al. 2015) as well as low-food availability (Serrano et al. 2018) (ESM3). In the present study, we could exclude all those factors since water and nutrient parameters were checked monthly and colonies were regularly fed. Therefore, the bail-out observed here was more likely related to a delayed effect of sampling and transport or rearing conditions per se, as observed in other species (Serrano et al. 2018). In a natural environment, A. subpinnata can be found at high densities (Bo et al. 2009) with overlapping branchlets; therefore, our experimental setup was similar to in situ conditions; however, different water circulation dynamics may have been a limiting factor. This species is known to be particularly sensitive to aquarium conditions with a previous study describing asexual reproduction through fragmentation in controlled environment (Coppari et al. 2019). Nevertheless, after 45 days, in order to avoid the death of the mother colonies, necrotic parts were removed and colonies transferred to a large exhibition tank, whose size and current circulation were probably more suitable for colonies. These colonies are still in good health two years after the experiment.

Similarly to previous studies, the settlement of bail-out propagules was not observed (ESM3). This might be related with the 45 days duration of our experiment, which is short compared to the 7 months of pre-settlement period reported for scleractinian bail-out propagules (Capel et al. 2014) or with the not optimal rearing conditions of the propagules (i.e., small glass beakers, lack of suitable substrate, insufficient water current). The long-term survival of non-feeding, motile propagules remains an open question, and it would be worth analyzing their lipid compositions to quantify their energetic reserves.

Information on the histological structure and anatomy of the bail-out propagules is lacking, and our results show a complete re-organization of the gastroderm with formation of vacuoles of unknown function and appearance of cilia. The presence of cnidocysts is documented although more limited in number and types.

Although the bail-out process is an extreme response to stressful conditions, the mechanisms underlying such processes are similar to polyp expulsion (tissue and polyp detachment); this means that species able to bail-out may also be able to release entire polyps as a reproductive mechanism. This form of asexual reproduction, in natural environments, might help to maintain scattered patches where sexual reproduction would not be effective due to the low density. The extended life span of the bail-out propagules (Capel et al. 2014), and potentially of the asexually produced ones, might favor long-distance dispersal under unfavorable conditions, having an ecological importance in the connectivity between populations. However, at present, this possibility for A. subpinnata can only be indirectly inferred from the high connectivity showed by genetic studies (Costantini et al. 2019) and reported also for the congeneric species A. fiordensis (Miller and Grange, 1997).

In cnidarians, asexual reproduction is considered an adaptation to unstable or unfavorable environments (Foster et al. 2007) and bail-out in particular, an extreme response to adverse conditions (Sammarco 1982). The capability of A. subpinnata to reproduce, by fragmentation and potentially by polyp expulsion, might guarantee the survivorship of this species and the colonization of more suitable environments, through propagules dispersal, in presence of 
human impacts (e.g., mechanical stress due to fishing activities) or climate change-related impacts. However, to ensure the genetic recombination and diversity through sexual reproduction, stronger management measures should be established to preserve these valuable vulnerable marine ecosystems.

Acknowledgements Authors would like to thank the Genova Voltri Carabinieri Military Force for their help during sampling procedures and SEM Laboratory of the Department of Earth, Environment and Life Sciences (UNIGE). The research leading to these results received Funding from the European Union's Horizon 2020 research and innovation program under Grant Agreement RL020220181629424, ASSEMBLE Plus Project, and from BIOMOUNT Project MIUR-SIR (RBSI14HC9O, Biodiversity patterns of the Tyrrhenian Seamounts).

Funding Open access funding provided by Università degli Studi di Genova within the CRUI-CARE Agreement.

\section{Compliance with ethical standards}

Conflict of interest The authors declare that they have no conflict of interest.

Ethical approval All applicable international, national and/or institutional guidelines for the care and use of animals were followed.

Open Access This article is licensed under a Creative Commons Attribution 4.0 International License, which permits use, sharing, adaptation, distribution and reproduction in any medium or format, as long as you give appropriate credit to the original author(s) and the source, provide a link to the Creative Commons licence, and indicate if changes were made. The images or other third party material in this article are included in the article's Creative Commons licence, unless indicated otherwise in a credit line to the material. If material is not included in the article's Creative Commons licence and your intended use is not permitted by statutory regulation or exceeds the permitted use, you will need to obtain permission directly from the copyright holder. To view a copy of this licence, visit http://creativecommons. org/licenses/by/4.0/

\section{References}

Bo M (2008) Taxonomy and ecology of antipatharians. Ph.D. Dissertation in Marine Biology and Ecology, Università Politecnica delle Marche, Ancona, Italy, p 212

Bo M, Montgomery AD, Opresko DM, Wagner D, Bavestrello G (2019a) Antipatharians of the mesophotic zone: four case studies. In Mesophotic Coral Ecosystems (pp. 683-708). Springer, Cham

Bo M, Bavestrello G, Di Muzio G, Canese S, Betti F (2019b) First record of a symbiotic relationship between a polyclad and a black coral with description of Anthoplana antipathellae gen. et sp. nov. (Acotylea, Notoplanidae). Mar Biod 49:2549-2570

Bo M, Bavestrello G, Canese S, Giusti M, Salvati E, Angiolillo M, Greco S (2009) Characteristics of a black coral meadow in the twilight zone of the central Mediterranean Sea. Mar Ecol Prog Ser 397:53-61

Capel KCC, Migotto AE, Zilberberg C, Kitahara MV (2014) Another tool towards invasion? Polyp "bail-out" in Tubastraea coccinea. Coral Reefs 33:1165
Cerrano C, Bastari A, Calcinai B, Di Camillo C, Pica D, Puce S, Valisano L, Torsani F (2019) Temperate mesophotic ecosystems: gaps and perspectives of an emerging conservation challenge for the Mediterranean Sea. The European Zoological Journal 86:370-388

Coppari M, Mestice F, Betti F, Bavestrello G, Castellano L, Bo M (2019) Fragmentation, re-attachment ability and growth rate of the Mediterranean black coral Antipathella subpinnata. Coral Reefs 38:1-14

Costantini F, Terzin M, Paletta MG, Coppari M, Bavestrello G, Abbiati M, Bo M (2019) Population genomics in Mediterranean vulnerable ecosystems: the case of the black coral Antipathella subpinnata. ICES ANNUAL SCIENCE CONFERENCE 2019, 9-12 September 2019 Gothenburg, Sweden

Fordyce AJ, Camp EF, Ainsworth TD (2017) Polyp bailout in Pocillopora damicornis following thermal stress. F1000Research 6:687

Foster NL, Baums IB, Mumby PJ (2007) Sexual and asexual reproduction in an ecosystem-engineer: the massive coral Montastrea annularis. J Anim Ecol 76:384-391

Gaino E, Scoccia F (2010) Gamete spawning in Antipathella subpinnata (Anthozoa, Antipatharia): a structural and ultrastructural investigation. Zoomorphology 129:213-219

Gohar HAF (1940) Studies on the Xeniidae of the Red Sea: their ecology, physiology, taxonomy and phylogeny. Publ Mar Biol Stn Al Ghardaqa 3:27-78

Gonçalves JF (2016) On the origin of bilaterality: insights from the study of black corals (Cnidaria: Antipatharia). Populations and Evolution [q-bio.PE]. Université Pierre et Marie Curie - Paris VI, English

Kariyazono ST, Hatta M (2015) Bail-out of the polyp from the skeleton of spats in the scleractinian coral Acropora tenuis. Galaxea 17:19-20

Kramarsky-Winter E, Fine M, Loya Y (1997) Coral polyp expulsion. Nature 387:137

Kružić P (2007) Polyp expulsion of the coral Cladocora caespitosa (Anthozoa, Scleractinia) in extreme sea temperature conditions. Natura Croatica 16:211

Kvitt H, Kramarsky-Winter E, Maor-Landaw K, Zandbank K, Kushmaro A, Rosenfeld H, Fine M, Tchernov D (2015) Breakdown of coral colonial form under reduced $\mathrm{pH}$ conditions is initiated in polyps and mediated through apoptosis. Proc Natl Acad Sci USA 112:2082-2086

Lee CS, Walford J, Goh BPL (2012) The effect of benthic macroalgae on coral settlement. In: Tan K-S (ed) Contributions to marine science: A commemorative, vol celebrating. 10 years of research on St John's Island. National University of Singapore, Singapore, pp 89-93

Miller K, Grange KR (1997) Population genetic studies of antipatharian black corals from Doubtful and Nancy Sounds, Fiordland, New Zealand. In: Proceedings of the 6th international conference on coelenterate biology, pp 353-363

Parker NR, Mladenov PV, Grange KR (1997) Reproductive biology of the antipatharian black coral Antipathes fiordensis in Doubtful Sound, Fiordland, New Zealand. Mar Biol 130:11-22

Peter K III, Rodgers KS, Jokiel PL, Lager CV, Lager DJ (2014) Effects of terrigenous sediment on settlement and survival of the reef coral Pocillopora damicornis. PeerJ 2:e387

Piraino S, De Vito D, Schmich J, Bouillon J, Boero F (2004) Reverse development in Cnidaria. Can J Zool 82:1748-1754

Rakka M, Bilan M, Godinho A, Movilla J, Orejas C, Carreiro-Silva M (2019) First description of polyp bailout in cold-water octocorals under aquaria maintenance. Coral Reefs 38:15-20

Rossi S, Bramanti L, Gori A, Orejas C (2017) An overview of the animal forests of the world. Marine Animal Forests: the ecology of benthic biodiversity hotspots. Springer, Cham, 1-28 
Sammarco P (1982) Polyp bail-out: an escape response to environmental stress and a new means of reproduction in corals. Mar Ecol Prog Ser 10:57-65

Schindelin J, Arganda-Carreras I, Frise E, Kaynig V, Longair M, Pietzsch T, Preibisch S, Rueden C, Saalfed S, Schimd B, Tinevez JY, White DJ, Hartenstein V, Eliceiri K, Tomankac P, Cardona A (2012) Fiji: an open-source platform for biological-image analysis. Nat Methods 9:676-682

Serrano E, Coma R, Inostroza K, Serrano O (2018) Polyp bail-out by the coral Astroides calycularis (Scleractinia, Dendrophylliidae). Mar Biodiv 48:1661-1665
Shapiro OH, Kramarsky-Winter E, Gavish AR, Stocker R, Vardi A (2016) A coral-on-a-chip microfluidic platform enabling liveimaging microscopy of reef-building corals. Nat comm 7:1-10

Wells CD, Tonra KJ (2020) Polyp bailout and reattachment of the abundant Caribbean octocoral Eunicea flexuosa. BioRxiv. https://doi.org/10.1101/2020.07.04.187930

Publisher's Note Springer Nature remains neutral with regard to jurisdictional claims in published maps and institutional affiliations. 